\title{
Supply Chain Finance for SMEs - Case in Danang City
}

\author{
Le Thi Minh Hang \\ The Faculty of Business Administration, University of Economics - The University of Danang \\ 71 Ngu Hanh Son, Danang, Vietnam \\ E-mail: hang.ltm@due.edu.vn \\ Nguyen Son Tung \\ The Faculty of Business Administration, University of Economics - The University of Danang \\ 71 Ngu Hanh Son, Danang, Vietnam \\ E-mail: tungns@due.edu.vn (Corresponding Author)
}

\begin{abstract}
Recently, the number of Vietnamese small and medium enterprises (SMEs) is rapidly growing. Since most of them are run under owner's capital, they easily face cash constraint situation during their operational life cycle. Hence, the demand for Vietnamese SMEs to optimize their liquidity has been increasing and becoming a top concern. Previous studies in the supply chain field focus much on the physical flow of products/services and informational flow. Meanwhile, the financial aspect as well as its sustainability in the supply chain has been received more attention after the financial crisis of 2008. This even gets more crucial when the uncertainties in the global economy and financial markets increase pressure on businesses' cash as well as their supply chains (SC). Considering the role of this concept and its potential, this study tries to explore and examine the level of understanding about the monetary supply chain of SMEs based in Danang city and how they can access financial sources for more stability and sustainable business. The truth is many SMEs face existing problems to access financial sources like banks as well as establishing a long-lasting SC. Without a doubt the fund-raising information infrastructure in Danang city is not well developed, and local businesses still depend on financial sources from banks. Also, the connection between buyers and suppliers is still weak as they do not invest much in the infrastructure or production line to create a common ground with the business's product characteristics. In addition to that, this paper suggests some implications for the development of the local SMEs in general and their supply chains in particular.
\end{abstract}

Keywords: Supply Chain Finance (SCF), cash constraint, financial flow, SMEs.

\section{INTRODUCTION}

In today's fast-changing business environment, the pressures of competition have become more aggressive. To develop and maintain an advantage, the whole supply chains' effectiveness and efficiency have to be of concern, instead of focusing on a single business. The studies in supply chain management have been devoted and focused on the improvement of physical and informational flow. However, the financial aspect of the supply chain has not received enough attention (Pfohl and Gomm, 2009). Indeed, previous research on financial aspects of SC mainly focuses on factoring and reverse factoring of accounts receivables so as to favorable the cash flow situation (Buzacott and Zhang, 2004; Tsai, 2011), as well as to optimize the firms' working capital positions (Hofmann, 2005; Aberdeen, 2011; Liu et al., 2015).

Considering the case of Vietnam, this emerging country has opened itself to the rest of the world since 1986 and most businesses and enterprises were state-owned during that time. With the fast-changing economic policy, Vietnamese small and medium enterprises (SMEs) have been playing an important role in improving Vietnam GDP and Vietnamese daily life (Sakai and Takada, 2000). Meanwhile, in this global competitiveness world, the collaboration between buyers and suppliers is more important than ever and it affects the survival of SC (Raghavan and Mishra, 2011). Nowadays, most of Vietnamese SMEs are run under owner's capital and they easily face cash constraint situation during their operation life cycle. This is a threat to Vietnams' economy in general; especially for fast-growing businesses, whose cash acts as an important factor of their successes. And history gave lessons before as Vietnams' economy faced a hard time during the financial crisis in 2008 and many businesses had to be foreclosed. This can be blamed on unstable liquidity and lack of cash for daily operations. Even after the financial crisis, many businesses saw their supply chains threatened by deficient free cash on hand. This led to increasing competition - this time not only among individual businesses but also among the entire supply chain. Therefore, alternative forms of financing became needed, especially trade credit from suppliers (Yan et al., 2016).

In a basic understanding, supply chain finance (SCF)is an approach to help businesses convert account receivable, stock on hand, monetary resources into cash and to improve funds accessibility by using buyers high credit rating (Hofmann, 2005; Aberdeen, 2011). This approach can reach out to SMEs by leveraging the existing supply chain relationships and gather a large number of SMEs into a formal financial system (Aberdeen, 2011; Gelsomino et al., 2016). By applying the SCF concept, every party in the SC can enter a win-win situations. This perspective has been concerned in recent researches, which have suggested that the supply chain has a direct and significant impact on the firm's monetary initiatives (Chen, 2012; Foster, 2015).In an emerging market, SCF enables the funding post-paid with 
competitive interest rates and makes the local suppliers more attractive to global buyers. Indeed, commercial banks in Vietnam already provide some financial tools such as loans, factoring, trade credit and Letter of Credit (L/C). However, there is potential risk or disruption in the supply chain due to the bargaining power related to trade credit whereby weaker suppliers would be forced to increase payment period or to delay the repayment (Boissay and Gropp, 2007; Raddatz, 2010; Caniato et al., 2016; Fabbri and Klapper, 2016).

Furthermore, the paperwork and the credit check for these services are of such complexity that not many small businesses can get through. And as supply chain has become more complex, its partners could include any business in or connected to the supply chain. One can distinguish 2nd and 3rd tier suppliers or even deeper in the chain (Hofmann, 2005). Considering SCF's potential, this study tries to explore and examine (1) the awareness of businesses based in Danang city about SCF and its benefits. (2) The options for local businesses and accessibility to financial sources.

From these findings, the study aims to bring out the whole picture of the SCF situation in Danang city and it will provide some recommendation to help local businesses optimize cash positions of individuals in general and whole supply chains in particular.

\section{LITERATURE REVIEW}

\subsection{Supply Chain Finance's Concept}

Supply Chain Finance (SCF) was early defined by (Hofmann, 2005) as an approach for two or more organizations in an existing supply chain that combined create value via controlling, planning, and steering the flow of financial resources on an inter-organizational level. This school of thought defines SCF as a broader concept of Supply Chain Management (SCM), which is the concept of improving the long-term performance of every individual business and its supply chain by using systematic and strategic collaboration between all functions within a business in particular and within the supply chain in general (Vallet - Bellmunt et al., 2011). Hofmann (2005) also suggests that businesses see external financial sources and logistics providers as internal factors of a supply chain, because he defined these services' collaboration as one single organism or entity.

Another approach defines SCF as a financial tool and a technology solution (He and Tang, 2012). SCF is a combination of trade financing and a technology platform that connects the trading partners and financial institution selectrically (Aberdeen, 2011). Based on this approach, orders and invoices will be verified and published using a technology platform. SCF is developed for SMEs as the main customers get access to financial sources by using the credit rating of core enterprises in a supply chain without getting through the traditional channels, which is a loan from a bank. SCF helps SME to put financial sources to their most productive use. Getting financial resources from traditional channels may be more difficult for SMEs because they lack fixed assets used to secure the loan and an unsatisfactory financial system with anenormous cash flow gap. Steeman (2014) adds that SCF focuses on providing liquidity on SCs throughout all pre- and post-shipment processes. SCF can help businesses lengthen their payment cycles by selecting invoices to disburse under cash constraint situations or to save money by paying via early payment programs under healthier conditions. SCF thereby touches all elements of working capital, which are calculated by dividing current assets to current liabilities in some level (Aberdeen, 2011).

It is clear that the full view of supply chain finance implicates a variety of different functional areas: the controller for account payable (A/P) and account receivable (A/R), Treasurer for cash management, sale for day sale outstanding (DSO) and the promotional element of day inventory outstanding (DIO), procurement for day payable outstanding (DPO), supply chain and manufacturing for inventory planning. Not only are these different elements the focus of different functional groups, but those groups may also have separate reporting lines to different executives. The emphasis of holistic supply chain finance then needs to be on executive-level engagement, to ensure that all the pieces are working towards a common goal, and not towards individual goals that summarized produce a less desirable result.

On another study, Raghavan and Mishra (2011) show that a lender who finances the manufacturer has a motivation to finance the retailer as well. They characterized the lenders decision problem in two ways: One, where one makes an independent decision on the loan amounts to the two firms and two where a joint decision is made. They performed a numerical study to understand the effects of joint decision on the lender's profit by changing various parameters. Their numerical study suggests that if either the retailer or the manufacturer has a sufficiently low level of cash, a joint decision is beneficial for the lender as well as for both the borrowing firms.

\subsection{Supply Chain Finance's Benefit}

The key idea behind SCF is to provide suppliers accessibility to advantageous financing facilities by leveraging the buyer's stronger credit rating and use it as a debt financing alternative and as a solution to improve collaborations conditions between businesses. From previous studies, the benefits of SCF can be divided into the following:

\section{A. For the Buyers}

The first benefit of SCF for buyers is that buyers can expect to have longer supplier payment terms without having to trade off against higher prices. Businesses that used SCF tend to have longer Days Payable Outstanding (DPO), which shows how businesses' effectiveness maximizes cash on hand (Aberdeen, 2011). This measurement is used to evaluate the organizations' ability in meeting their shortterm obligations. The problem, of course, is that not all current assets are created equal. Cash on hand can be immediately employed to settle debts but may be more effectively used for short-term investment. Inventory, given the concern of demand volatility, is not as reliably converted to cash and can be costly to carry over time due to storage and obsolescence (Kleijnen and Smits, 2003; Jing and Seidmann, 2014). The second benefit to mention is the possibility to straighten out time solution and automation, as SCF are based on technology platforms, businesses can eliminate paperwork and speed up the information transition (He and Tang, 2012). Furthermore, buyers could reap early settlement discounts which flow directly into profits while still paying at invoice maturity. Indeed, theyreceive cheaper short-term financing from the supplier, and later in return 
may be asked to grant longer payment terms (Vliet et al.,2015; Wuttke et al., 2016).

\section{B. For the Supplier}

Beside the benefits to buyers, SCF paves the way for suppliers to gain many advantages as well. From previous studies, these advantages can be listed as follows:

- Lower trade receivables and increase in cashposition: As SCF increases an extension in buyers' DPO, this leads to an increase in Accounts Payable (AP), which means the buyers have more cash on hand to finance their value-created processes (Aberdeen, 2011; Rogers et al., 2016). However, later payments mean later cash inflow for suppliers and if the delaying payments happen outside of the contracts term, buyers have to pay some late-payment penalties. This could affect the businesses' relationship or the connection between buyers and suppliers. The SCF concept can help prevent this situation by adding a financial institution (Hofmann, 2010). In this case, buyers can lengthen their payment period, suppliers can receive money earlier and financial institutions can profit from charging a discount rate. The result is an extension of DPO for the buyer without the equivalent shortage of cash for the supplier. As long as such gains are not offset by price increases on the buy-side (Aberdeen, 2011).

- Faster access to cash at advantageous rates: SCF is an impawn financing pricing model under conditions of acceptable delay in payments; the model considers both backorders and backlogging as well as a discount episode (Yang, 2013). Depending on the real economic situation and the financial status of the SC partner the financing can be done by the suppliers, core enterprises or the distributors (He and Tang, 2012).

- Stronger cooperation with the buying business creates a competitive advantage: with a strong connection and collaboration, businesses are encouraged to collaborate with an external and internal partner within a SC. This collaboration is based on trust and will lead to a longterm trading relationship (Hofmann, 2005; Aberdeen, 2011).

- Transparency: when businesses use technology platforms to make financial transactions, both internal and external information are exchanged between two financial institutions and businesses inside a SC. Thus, these make visible share events between individuals inside a SC, so risk is mitigated (He and Tang, 2012; Rogers et al., 2016).

- Controlling: Because of transparency and predictability, businesses can identify potential problems and prepare actions/ solutions to comply both internal and external standard (Hofmann, 2010). SCF has been commonly used to balance the cash flow along the supply chain. It performs as a backup source of capital for many firms during financial crises or monetary contractions, because suppliers can have a better control of buyers than the financial institutes. Many firms also allow their partners to settle the payment after a fixed period without any requirement as a way to trigger them to make the order, increase sale, increase the order volume, cut down the transaction cost, improve the product availability, enable the retailers to earn profit without paying too much money, which may excess their financial ability with less risk, in some case, customers are willing to pay more promptly in a bid to take advantage of trade credit more frequently (Thangam and Uthayakumar, 2009).

- Prediction: by using automation to make financial transactions and information exchange, this will help businesses in accessing to various sources of data and analysis. From that the manager team could make a future prediction on demand (Aberdeen, 2011).

- Quicker cash conversion: traditionally, commercial credit policy affects the cash cycles in a supply chain. Normally some cash is tied up in non-value created processes, so it was a potential to free this extra cash and optimize financial flows in the SCs. Also, remember that commercial credit as well as short-term borrowing, is the most expensive financial instrument in the range of financial products (Hofmann, 2010).

From literature review section, the key idea behind SCF is to provide suppliers an access to advantageous financing facilities by leveraging the buyers stronger credit rating and to improve collaborations conditions between businesses in a supply chain, which can increase the competitiveness of the whole supply chain. In this study, we aim to explore (1) the awareness of businesses, based in Danang city, about SCF and its benefits. (2) What and how local businesses can get access to financial sources? The finding of this study will partly bring out some problems in financial flow that local businesses faced and suggest some implications for the development of the local SMEs in general and their supply chain in particular.

\section{RESEARCH METHODOLOGY}

In order to objectively and accurately describe the current cash position of businesses in Danang city, the research team uses qualitative research methods. This section shows the procedure of building qualitative surveys questionnaires and choosing target respondents as follows. Based on the research by Aberdeen Group (2011), our questions focus on these issues: (1) the awareness of local businesses about SCF and its benefits; (2) how local businesses can get access to financial sources. Leadership decision making was also used to see the difference (in leadership roles) of willingness in making a joint decision (Raghavan and Mishra, 2011). Our target respondents in this research vary from employees up to managers and owners who work in businesses and corporations located in Danang city.

The survey contains three sections as follows:

- The first section contains 19 questions and mainly focuses on the condition of the business and the knowledge of respondent on SCF.

- The second section contains 15 questions and mainly focuses on the relationship of the respondent's business with its supplier, and how cash is transferred from one to the other.

- The third section contains 19 questions and mainly focuses on the relationship of the respondent's business with its buyer, and how cash is transferred from one to the other. 
We sent out five hundred surveys via email and the study was conducted in Danang city from April to August 2018.

\section{RESULTS AND DISCUSSION}

Table 1 Descriptive information of sample

\begin{tabular}{|l|l|c|}
\hline \multicolumn{2}{|c|}{ Demographic factors } & Percentage \\
\hline \multirow{2}{*}{ Geography } & $\begin{array}{l}\text { Businesses are headquartered or } \\
\text { branded in Danang city }\end{array}$ & $100 \%$ \\
\hline \multirow{3}{*}{ Job title } & Deputy Director and above & $42 \%$ \\
\cline { 2 - 3 } & Manager & $34 \%$ \\
\cline { 2 - 3 } & Staff & $24 \%$ \\
\hline \multirow{3}{*}{$\begin{array}{l}\text { Business } \\
\text { size }\end{array}$} & Supper small enterprises & $49 \%$ \\
\cline { 2 - 3 } & Small enterprises & $17 \%$ \\
\cline { 2 - 3 } & Medium enterprises & $16 \%$ \\
\cline { 2 - 3 } & Large enterprises & $18 \%$ \\
\hline
\end{tabular}

The table above provides a description of the characteristics of sample respondents. There are a total of 94 respondents to the survey, who work for businesses that are headquartered or branded in Danang city, in which the people who hold the position of Deputy Director and above gain the most popularity with $42 \%$, followed closely by manager and staff who represent $34 \%$ and $24 \%$ of respondents respectively. Given this, more than $70 \%$ of respondents are in charge of decision making. Hence, the information from the survey would be valuable at a strategic dimension.

Considering the category of business size, the super small enterprises, which have an average annual revenue in the last 3 years less than 10 billion VND, are the highestrated group with $49 \%$. The 3 remaining groups, including large enterprises (over 100 billion VND in average annual revenue of the last 3 years), small enterprises (10 - 49 billion VND in average annual revenue of the last 3 years) and midmarket ones $(50-99$ billion VND in average annual revenue of the last 3 years) lag far behind with only 18\%, 17\% and $16 \%$ respectively. Another noticeable thing is that these businesses come from a variety of industries, which are as follows: service \& trading, agriculture, forestry \& fisheries branch, and industry \& construction.

\subsection{Awareness About SCF of SMEs Based in Danang City}

The primary data was collected from April to August 2018, of which nearly 122 participants (account for 24.4\%) responded back to our survey. After obtaining feedback data from the respondents, we conducted a simple read-through to eliminate the off-topic or non-related answers and gave an overview of the data obtained. The final respondents included 72 leaders (roles of team leader to director) and 22 staffs. Then, by reading each answer and identifying relevant keywords, the frequency, of the authors appearing to classify these keywords into response groups may be found in the later study. follows:

We were able to identify a brief overall picture as

1. Most businesses use financial tools from banks.

2. Most businesses do not cooperate because they are afraid of quality in trade.

3. Respondents, who understand SCF, mostly hold a manager title or regional managers.

After finishing the survey data-gathering, we calculated the statistics value. From 94 respondents, 65 of them (account for $69 \%$ ) had some knowledge about SC, whereas 28 of them (account for $29.78 \%$ ) did not know about SC, and 1 of them (account for $1.22 \%$ ) did not answer the question.

Table 2 shows that employees with higher positions have better understanding and knowledge about SC and SCF. Starting from 22 respondents who are in staff position, 8 of them (account for 36.36\%) could not give a brief understanding about SC and 1 of them (account for $4.55 \%$ ) had heard about SCF before. The portion of understanding about SC and SCF increases in group of employees with higher positions. In the group of 32 respondents, who hold a role as head of department, 26 of them (account for $81.25 \%$ ) understood about SC and 7 of them (account for 26.92\%) had heard or could give a brief definition about SCF. And finally, among 40 respondents, who hold a role as deputy director or above, 31 of them (account for $77.5 \%$ ) understood about SC and 6 of them (account for 15\%) had heard or could give a brief definition about SCF.

Table 2 Level of job title relative to the understanding of SC and SCF

\begin{tabular}{|c|c|c|c|c|c|}
\hline Role & Department & Number & $\begin{array}{c}\text { Quick } \\
\text { understanding } \\
\text { about SC }\end{array}$ & $\begin{array}{l}\text { Quick understanding } \\
\text { about beginning and } \\
\text { ending of business } \\
\text { SC }\end{array}$ & $\begin{array}{c}\text { Quick } \\
\text { understanding } \\
\text { about SCF }\end{array}$ \\
\hline \multirow{4}{*}{ Staff } & Sale & 11 & 1 & 1 & 1 \\
\hline & Sales Management / Market Management & 4 & 3 & 3 & 0 \\
\hline & Production & 4 & 1 & 1 & 0 \\
\hline & Upstream Supply chain & 3 & 3 & 3 & 0 \\
\hline \multicolumn{2}{|r|}{ Total } & 22 & 8 & 8 & 1 \\
\hline \multirow{2}{*}{$\begin{array}{c}\text { Head of } \\
\text { department }\end{array}$} & Sale & 12 & 10 & 8 & 1 \\
\hline & Sales Management / Market Management & 4 & 4 & 1 & 0 \\
\hline
\end{tabular}


Table 2 Level of Job Title Relative to the Understanding of SC and SCF (con't)

\begin{tabular}{|c|c|c|c|c|c|}
\hline & Planning & 3 & 3 & 3 & 3 \\
\hline & Supervision of construction works & 3 & 3 & 3 & 0 \\
\hline & Production & 3 & 3 & 3 & 3 \\
\hline & Upstream Supply chain & 1 & 0 & 0 & 0 \\
\hline & Marketing & 1 & 0 & 0 & 0 \\
\hline & Legislation & 1 & 0 & 0 & 0 \\
\hline & Human resource & 1 & 0 & 0 & 0 \\
\hline & Food and vegetable & 3 & 3 & 3 & 0 \\
\hline & Total & 32 & 26 & 21 & 7 \\
\hline \multirow{6}{*}{$\begin{array}{l}\text { Deputy } \\
\text { Director } \\
\text { and above }\end{array}$} & Sale & 12 & 8 & 8 & 1 \\
\hline & Sales Management / Market Management & 11 & 11 & 11 & 0 \\
\hline & Owner & 5 & 3 & 3 & 0 \\
\hline & Operation & 4 & 4 & 4 & 3 \\
\hline & Production & 4 & 1 & 1 & 1 \\
\hline & Management & 4 & 4 & 4 & 1 \\
\hline \multicolumn{2}{|r|}{ Total } & 40 & 31 & 31 & 6 \\
\hline
\end{tabular}

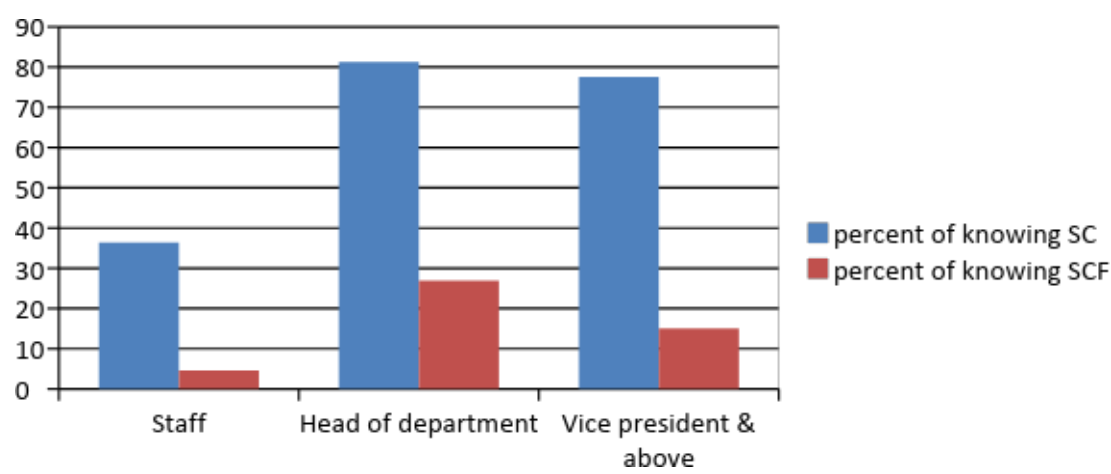

Figure 1 Comparing the relationship between job position with the understanding about SC and SCF

In 11 respondents knowing about SCF, 8 of them (account for $72.73 \%$ ) could give their own brief definition about SCF as following:

Table 3 Respondents' SCF definition

\begin{tabular}{|l|c|}
\hline \multicolumn{1}{|c|}{ Definition (original quotes) } & $\begin{array}{c}\text { Number of } \\
\text { respondents }\end{array}$ \\
\hline "SCF for me is known as the provision of capital to each of the chain in order to bring success across that whole SC." & 1 \\
\hline "SCF is a financing of working capital loans for suppliers and distributors in the chain." & 2 \\
\hline $\begin{array}{l}\text { "SCF is a financing solution from suppliers to distributors, and to distribution channels spread across the country. With } \\
\text { preferential policies throughout the banking system, distributors and suppliers will enjoy outstanding incentives } \\
\text { including preferences on account transaction costs, guarantee fees, interest rates for borrow. With this package, } \\
\text { distributors and suppliers can access loans quickly and promptly with interest rates cheaper from 1\% - 2\% per year } \\
\text { than ordinary customers, in which will help businesses have more flexible on capital, saving costs and transaction time. } \\
\text { In addition, suppliers are supported by the bank to assess the credibility of the buyer and advance up to } 80 \% \text { of } \\
\text { receivables without collateral through factoring services." }\end{array}$ & 1 \\
\hline $\begin{array}{l}\text { "SCF is a co-financing of working capital loans to suppliers and businesses. This solution provides suppliers and } \\
\text { business a secure and stable financial and helps business pay their debt on time." }\end{array}$ & 3 \\
\hline $\begin{array}{l}\text { "Supply Chain Finance (SCF) is a new approach to financial support. SCF is a partnership between businesses and } \\
\text { financial institutions. These financial institutions provide funding support to their suppliers and distributors." }\end{array}$ & 1 \\
\hline
\end{tabular}

From Table 1, most of respondents, could define and saw SCF as a financial solution, that helps increase businesses' working capital. This understanding is equivalent to the definition of (Hofmann, 2010). Also, sixtytwo respondents (account for $65.96 \%$ ) want to learn more about SCF and its benefits. Local businesses already see the benefit of the SCF, but can they easily establish a financing trade with their suppliers or will they provide financial packages to their buyers?

\subsection{Local Businesses' Financial Sources}

In 94 respondents, 27 respondents gave a blank on the question 12: "Does your business use financial services from banks or financial institutions?", 51 respondents (account for 
$54.26 \%$ ) took working capital loan and used financial services, such as $\mathrm{L} / \mathrm{C}$ and factoring from banks, 15 respondents (account for 15.96\%) neither use financial services from the bank or the financial institution. From data analyzed, $100 \%$ of respondents listed out the difficulties in obtaining a bank loan or using bank financial services (Figure 2). The difficulty in obtaining the bank loan is a well-known story that has not been solved yet. The bank has policies to develop small business credit, but these businesses must also meet the bank's risk management criteria such as collateral regulation, feasible business plans and accounting books. However, most of small businesses do not meet these regulations. Therefore, it is difficult for banks to make decisions on lending working capital (Chen, 2012). Also, $41.67 \%$ respondents answered that the most difficult part in obtaining working capital from a bank is the high interest rate and not all assets are accepted as collateral.
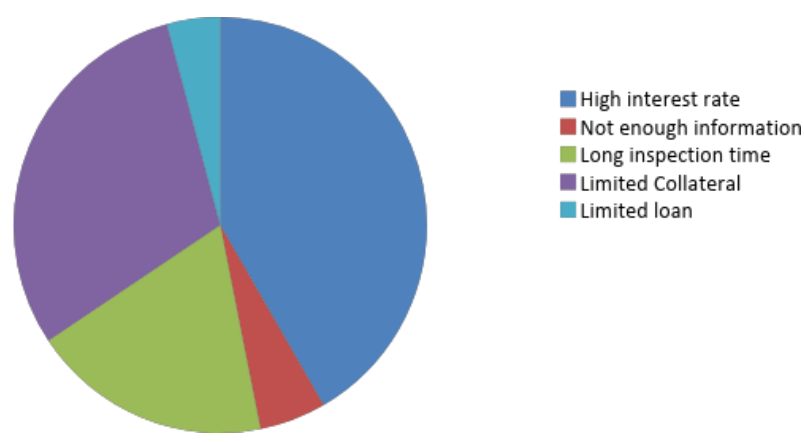

Figure 2 Factors of the difficulty in obtaining a bank loan

Table 4 shows that respondents in higher position are more willing to do trade financing with their suppliers. Is that easy to establish a trade financing with supplier? Figure 3 shows that the highest difficulty in doing trade financing with suppliers is that they provide an inequality of goods (account for $44 \%$ ), which in return would affect the revenue of the business. Fifty four respondents(account for 57.45\%) agree that the supplier's product can easily be replaced by other suppliers and 55 respondents (account for 58.5\%) state that their businesses have a low cohesion with their supplier (low cohesion means that business and its supplier do not invest must on the infrastructure or production line to compatible with the business's product characteristics) (Carnovale et al., 2018), which means the relationship between businesses and its supplier is not strong enough.

Table 4 The willingness to do a trade financing between businesses with their suppliers

\begin{tabular}{|l|c|c|c|c|}
\hline Position & $\begin{array}{c}\text { Loan } \\
\text { from } \\
\text { bank }\end{array}$ & $\begin{array}{c}\text { Trade financing } \\
\text { cooperation } \\
\text { with suppliers }\end{array}$ & $\begin{array}{c}\text { Not } \\
\text { respond }\end{array}$ & Total \\
\hline Staff & 7 & 1 & 14 & 22 \\
\hline $\begin{array}{l}\text { Head of } \\
\text { department }\end{array}$ & 15 & 13 & 4 & 32 \\
\hline $\begin{array}{l}\text { Vice } \\
\text { president } \\
\text { and above }\end{array}$ & 13 & 18 & 8 & 40 \\
\hline
\end{tabular}

On the other hand, the percentage of information flow between businesses is quite good $(80 \%$ businesses commit- ted that they usually announce to their suppliers if new information occurred). Also, $64.89 \%$ of businesses signed a long-term contract with their supplier. However, the fact shows a picture of conflict. Although local businesses in Danang city want to do trade financing with their suppliers and even sign a long - term contract, there is still a limitation towards/regarding real actions in investing to increase product quality and tie-up the supply chain.

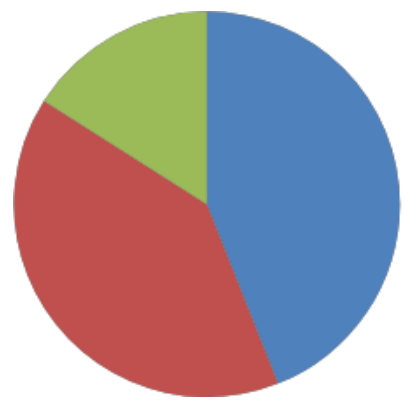

inequality of Goods Limited cooperative time Higher discount rate

Figure 3 Factors of the difficulty in doing trade financing with suppliers

Table 5.

\begin{tabular}{|l|l|l|l|l|}
\hline \multicolumn{1}{|c|}{ Difficulty } & $\begin{array}{c}\text { Average } \\
\text { cooperative } \\
\text { time }\end{array}$ & $\begin{array}{c}\text { Confident } \\
\text { in } \\
\text { supplier } \\
\text { (> } \\
\text { believe) }\end{array}$ & $\begin{array}{c}\text { Supplier's } \\
\text { products } \\
\text { easily } \\
\text { replace }\end{array}$ & $\begin{array}{c}\text { The } \\
\text { degree } \\
\text { of } \\
\text { cohesion } \\
\text { (low) }\end{array}$ \\
\hline $\begin{array}{l}\text { Inequality of } \\
\text { Goods }\end{array}$ & 4.58 years & $82.14 \%$ & $64.29 \%$ & $64.29 \%$ \\
\hline $\begin{array}{l}\text { Limited } \\
\text { cooperative } \\
\text { time }\end{array}$ & 4.16 years & $73.91 \%$ & $82.61 \%$ & $47.83 \%$ \\
\hline $\begin{array}{l}\text { Higher } \\
\text { discount rate }\end{array}$ & 5.36 years & $77.78 \%$ & $44.45 \%$ & $11.11 \%$ \\
\hline
\end{tabular}

\subsection{Local Businesses SCF Practices}

The most common SCF practices that local businesses used, are factoring and L/C (account for 7.34\%). By using factoring service, a supplier can sell its accounts receivable, such as invoices, to the bank or financial institution with a discount. By doing this, the supplier can receive cash right away to continue its production. Also, the bank can provide a credit rate to both of the parties. As a result, the data shows that businesses using SCF practices have a higher DPO, which means they could extend the payment term and pay their suppliers later.

Comparing DPO between businesses using SCF practices and not using SCF practices shows that in the most effective situation, the ones who apply SCF can take 3 months to pay its bill and invoices, marking a high level of DPO. Meanwhile, the others just take only a month.

\section{MANAGERIAL IMPLICATIONS}

This study provides some significant managerial implications for managers and government in the following ways. Firstly, our findings indicate the concept of SCF and the huge expected benefits when SCF is implemented for all the parties involved in the SCF, including the buyer, supplier, financial service provider (FSP), and technology service provider. This not only helps to create awareness but also create the motivation to apply, improve as well as enhance 
the SCF solutions. SMEs, who are historically unaware and hesitant to explore alternative instruments may be encouraged to apply SCF. In the next stage, after the awareness of SCF has been established, the policymakers should promote the adoption of SCF models as an alternative financing solution. The big buyers should facilitate these solutions to their suppliers and to the financial institution, looking for a win-win situation rather than thinking about their own achievements. Also based its meaningful benefits, financial and technology service providers could promote their services and solutions for better satisfying their clients' expectations.

Secondly, it goes without saying that SCF can be viewed as an instrument that improves the performance of all the supply chain, hence the concern is that how the parties can efficiently adopt and implement SCF strategies. This study also discusses about SCF solutions, which could be used as guidelines for businesses, e.g, buyers and suppliers should adopt electronic invoices and automatic approvals. This brings two benefits to both buyers and suppliers as first it achieves the transparency of the information and also facilities the exchange of electrical document between partners, which brings more trust for each party. Second, it allows buyers to have more control over their payment term. Also, the understanding of SCF solutions can bring about benefits for FSPs and helps them to make better decisions in offering technology-fitting solutions. They can build completed SCF products that cover all the scenarios included in the trade processes, ranging from the management of account receivables, the debtor's financial credit, inventory to the idle capital for using in the short term. Moreover, these financial products can be developed by the buyers/suppliers themselves, which enables the products to integrate systems and improve processes' transparency easily. These are the solutions to the weak connection between buyers and suppliers. To do that, infrastructure development, especially in the field of information must be put on top priority.

Besides the business enterprises, the Vietnamese Government in general and the Government of Danang city, in particular, should consider some measured policies to promote the SCF adoption. They need to focus on developing information infrastructure and building support policies for enterprises that evolved in SCF adoptions, especially financial institutions who directly developing SCF products. Moreover, a legislative framework should be established to ensure SCF activities run smoothly as well as ensure the rights of all involved parties.

\section{CONCLUSION}

The results have pointed out some existing problems. There are several difficulties of local businesses in accessing financial sources from banks as well as establishing a longterm relationship within its SC. In addition, local businesses still have limited knowledge about SCF and its benefits. There is no doubt that the information infrastructure in Danang city is not well developed, and local businesses still depend on financial sources from banks. Also, the connection between buyers and suppliers is still weak as they do not invest much on the infrastructure or production line to be compatible with the business's product characteristics.
From the results, this study provides some significant managerial implications for managers and government. Apart from the constructive contributions, this research still has some limitations meaning it is just a case study about the awareness of the SCF in Danang city and there are some difficulties in data-gathering such as the flaw of information. However, its results are realistically practical and could be considered as a meaningful reference, which shows a picture of the difficulties in accessing capital of local businesses and provide some suggestions that can help these businesses in achieving the control of working capital as well as establishing a transparency connection between buyers and suppliers.

\section{REFERENCES}

Aberdeen Group. (2006). New Strategies for Financial Supply Chain Optimization. pp. 1-34.

Aberdeen Group. (2011). Supply Chain Finance: Gaining Control in the Face of Uncertainty. pp. 1-23.

Boissay, F., and Gropp, R. (2007). Trade credit defaults and liquidity provision by firms. ECB Working Paper 753, pp. 1-44.

Buzacott, J.A., and Zhang, R.Q. (2004). Inventory management with asset-based financing. Management Science, 50(9), pp. 1274-1292.

Caniato, F., Gelsomino, L., Perego, A., and Ronchi, S. (2016).Does finance solve the supply chain financing problem? Supply Chain Management: An International Journal 21(5), pp. 534-549.

Carnovale, S., and Dale S, R., and Sengun, Y. (2018). The Performance Impacts of Network Power and Cohesion. Journal of Purchasing and Supply Management, pp. 1-12.

Chen, Y. (2012). Research on Risk of Supply Chain Finance of Small and Medium-Sized Enterprises Based on Fuzzy Ordinal Regression Support Vector Machine. International Journal of Business and Management 7(8), pp. 115-122.

Fabbri, D., and Klapper, L. F. (2016). Bargaining power and trade credit. Journal of Corporate Finance 41, pp. 66-80.

Foster, F. (2015). "Guest Voices: Overcoming the Challenges of Merging Supply Chains." The Wall Street Journal. Accessed July 10, 2019. https://www.wsj.com/articles/guest-voicesovercoming-the-challenges-of-merging-supply-chains1444070054

Gelsomino, L. M., Mangiaracina, R., Perego, A., and Tumino, A. (2016). Supply Chain Finance Modelling a Dynamic Discounting Programme. Journal of Advanced Management Science 4(4), pp. 283-291.

He, X., and Tang, L. (2012). Exploration on Building of Visualization Platform to Innovate Business Operation Pattern of Supply Chain Finance. Physics Procedia 33, pp. $1886-93$.

Hofmann, E. (2005). Supply chain finance: Some conceptual insights. In Beiträge $\mathrm{Zu}$ Beschaffung Und Logistik. Wiesbaden: Springer Gabler, pp. 203-214.

Hofmann, E., and Kotzab, H. (2010). A supply chain-oriented approach of working capital management. Journal of Business Logistics 31 (2), pp. 305-330.

Jing, B., and Seidmann, A. (2014). Finance sourcing in a supply chain. Decision Support Systems 58, pp. 15-20.

Kleijnen, J. P. C., and Smits, M. T. (2003). Performance Metrics in Supply Chain Management Performance metrics in supply chain management. Journal of the Operational Research Society 54, pp. 507-514.

Liu, X., Zhou, L., and Wu, Y. J. (2015). Supply Chain Finance in China: Business Innovation and Theory Development. Sustainability 7, pp. 14689-14709. 
Pfohl, H. C., and Gomm, M. (2009). Supply chain finance: Optimizing financial flows in supply chains. Logistics Research 1 (3-4), pp. 149-61.

Raddatz, C. (2010). Credit chains and sectoralcomovement: Does the use of trade credit amplify sectoral shocks? The Review of Economics and Statistics 92(4), pp. 985-1003.

Raghavan, N. R. S., and Mishra, V. K. (2011). Short-term financing in a cash-constrained supply chain. International Journal of Production Economics 134(2), pp. 407-412.

Rogers, D., Leuschner, R., and Choi, T.Y. (2016). The Rise of FinTech in Supply Chains. Accessed July 10, 2019. https://hbr.org/2016/06/the-rise-of-fintech-in-supply-chains.

Sakai, H., and Takada, N. (2000). Developing small and mediumscale enterprises in Vietnam. NRI Papers No. 13, Nomura Research Institute, Japan.

Steeman, M. (2014). The Power of Supply Chain Finance: How companies can apply collaborative finance models in their supply chain to mitigate risks and reduce costs. Windesheimreeks Kennis en Onderzoek nr. 50, pp. 1-21.

Thangam A., and Uthayakumar. R. (2009). Two-echelon trade credit financing for perishable items in a supply chain when demand depends on both selling price and credit period. Computers \& Industrial Engineering 57(3), pp. 773-786.

Tsai, C. Y. (2011). On delineating supply chain cash flow under collection risk. International Journal of Production Economics 129(1), pp. 186-194,
Vallet-Bellmunt, T., Martines-Fernandes, T., and Capo-Vicedo, J. (2011). Supply chain management: a multidisciplinary content analysis of vertical relations between companies, 1997-2006. Industrial Marketing Management 40(8), pp. 1347-1367.

Vliet, K. V. D., Reindorp, M. J., and Fransoo, J. C. (2015). The price of reverse factoring Financing rates vs. payment delays. European Journal of Operational Research 242(3), pp. 842853.

Wuttke, D. A., Blome, C., Heese, H. S., and Protopappa-sieke, M. (2016). Supply chain finance Optimal introduction and adoption decisions. International Journal of Production Economics, 178 (C), pp. 72-81.

Yan, N., Sun, B., Zhang, H., and Liu, C. (2016). A partial credit guarantee contract in a capital-constrained supply chain: Financing equilibrium and coordinating strategy. International Journal of Production Economics 173, pp. 122133.

Yang, M. (2013). Research on Supply Chain Finance Pricing Problem under Random Demand and Permissible Delay in Payment. Procedia Computer Science 17, pp. 245-57.

Le Thi Minh Hang is currently a Vice dean at the Faculty of Business Administration, University of Economic - The University of Danang, Vietnam. She received her Ph.D. from Grenoble II University, France. Her research interests include supply chain management, sustainable operations, and entrepreneurship. She teaches courses related to supply chain management, total quality management, operations management, and entrepreneurship and their application in business and society. Her research work has been published in the journals of high repute. She is on Editorial Boards and a regular reviewer of research works.

Nguyen Son Tung is currently a Lecturer at the Faculty of Business Administration, University of Economic - The University of Danang, Vietnam. He received his Master's degree in Business Administration from Dominican University of California, the US and is planning to begin his $\mathrm{PhD}$ in Belgium. His research interests include supply chain management and entrepreneurship. He can be reached at tungns@due.edu.vn. 